GEOLOGICA BALCANICA, 47 (1), Sofia, May 2018, pp. 61-71.

\title{
Fossil fault zones: significance and applications
}

\author{
Mohsen Ehteshami-Moinabadi \\ Department of Sedimentary Basins and Petroleum, Shahid Beheshti University, 1983969411 Tehran, Iran; \\ e-mail: m_ehteshami@sbu.ac.ir
}

(Accepted in revised form: March 2018)

\begin{abstract}
Fossil faults are permanently inactive fault zones, preserved and recognized in the geological record of an area by major brittle, semi-brittle, or mylonitic fault rocks, showing significant width and displacement. Applications and purposes of fossil fault researches include, but are not limited to, investigation on seismic faulting, analog model of active faults, metal ore deposits, paleo-path and fluid migration, deformation mechanism and fault migration along-strike and down-dip. These categories involve subsidiary subjects, some of which are relatively new and seem to attract more attention. Fossil faults are a major source of information about past geological processes that were active at some depth in Earth's lithosphere, and also provide an opportunity for assuming and predicting the future in structural geology. This paper reviews the researches done on fossil faults and their applications since the early 1970s, albeit not always listed as "fossil faults".
\end{abstract}

Ehteshami-Moinabadi, M. 2018. Fossil fault zones: significance and applications. Geologica Balcanica 47 (1), 61-71.

Keywords: fossil faults, deformation, seismic faulting, fluid migration, ore deposits.

\section{INTRODUCTION}

Fossil fault, inactive fault, dormant fault, and dead fault are some of the terms that are used in different ways to describe faults without observable activity. Inactive fault is a term mainly used in seismotectonics and active tectonics contexts. Sometimes, it refers to faults that have had movements during the Holocene or the last 10,000 years (e.g., USGS, 2017). However, a more academic definition of inactive faults is a fault with one movement during the last 35,000 years or more movements during the last 500,000 years, according to the US NRC Guidelines, part 100 (US NRC, 2017). Jackson (1999) explained that faults may become inactive for a period of time (dormant fault) or permanently (dead fault). Fault dormancy, or death, is sometimes the result of spatial migration of activity, switching between faults (Jackson, 1999), or fault zone migration in general (e.g., Leeder et al., 2008; Ehteshami-Moinabadi, 2014). Therefore, fossil faults are permanently inactive fault zones, preserved and recognized in the geological record of an area by major brittle, semi-brittle, or mylonitic fault rocks, showing significant width and displacement. Fossil faults have not had any activity since the Pliocene (Fig. 1). The aim of this paper is to highlight and review the significance and applications of studies on fossil faults.

\section{Evidence and criteria to distinguish fossil faults}

Distinguishing between fossil faults and other faults requires detailed field assessment of structures and especially cross-cutting relationships. Mylonitic rocks are products of fossil ductile shear zones; however, long-standing deep-seated active reverse faults can also exhume plastically deformed rocks from the lower crust (e.g., Miller, 2003; Meigs et al., 2006; Ehteshami-Moinabadi and Yassaghi, 2007; Suppe et al., 2015; Lacombe and Bellahsen, 2016). Figure 2 shows some criteria for recognition of fossil faults. Fault zones covered or displaced by younger faulted blocks (e.g., Neogene thrust fault) should generally be considered as fossil faults (Fig. 2a). EhteshamiMoinabadi et al. (2012) and Ehteshami-Moinabadi and Yassaghi (2013) reported an example, where the eastern portion of the Taleqan Fault is partially covered by an Oligocene-Miocene thrust fault. Passive change of fault-dip direction (Fig. $2 b$ ) or folding of fault zones in meso-scale (Fig. 2c) or map-scale (e.g., 

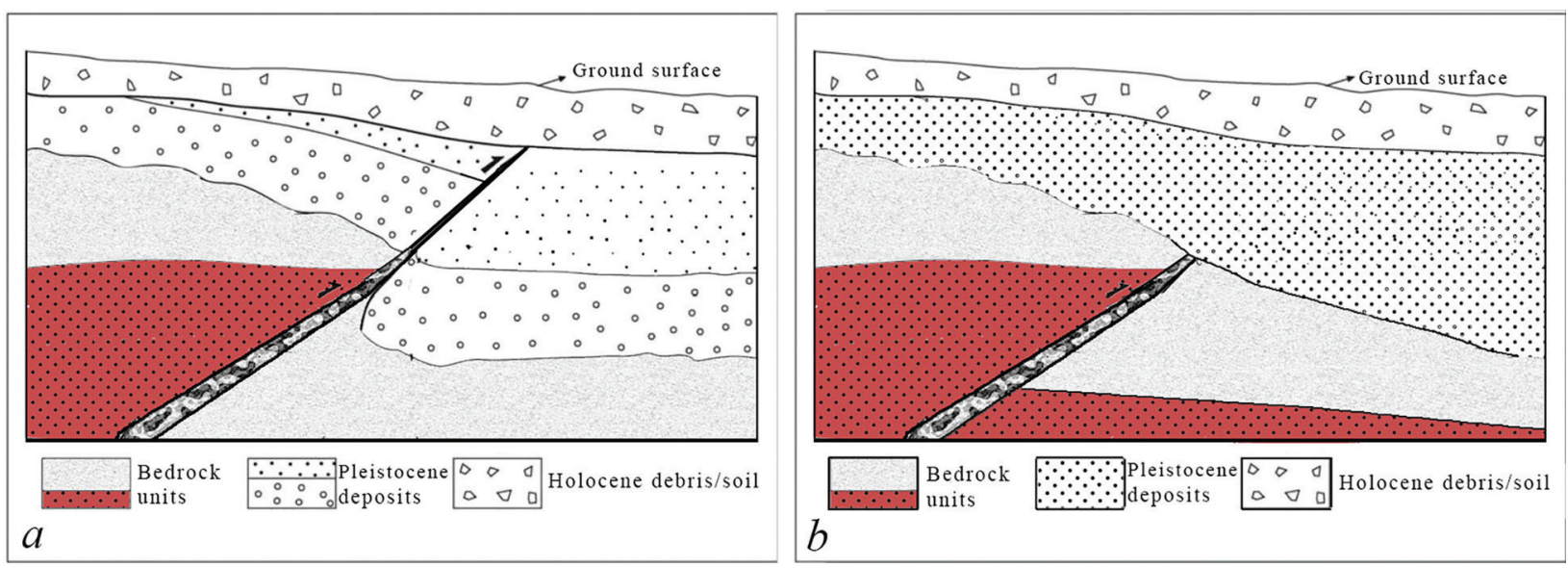

Fig. 1. Schematic drawings for differentiation between inactive $(a)$ and fossil faults $(b)$. Fossil faults have not had any activity since at least the Pliocene.
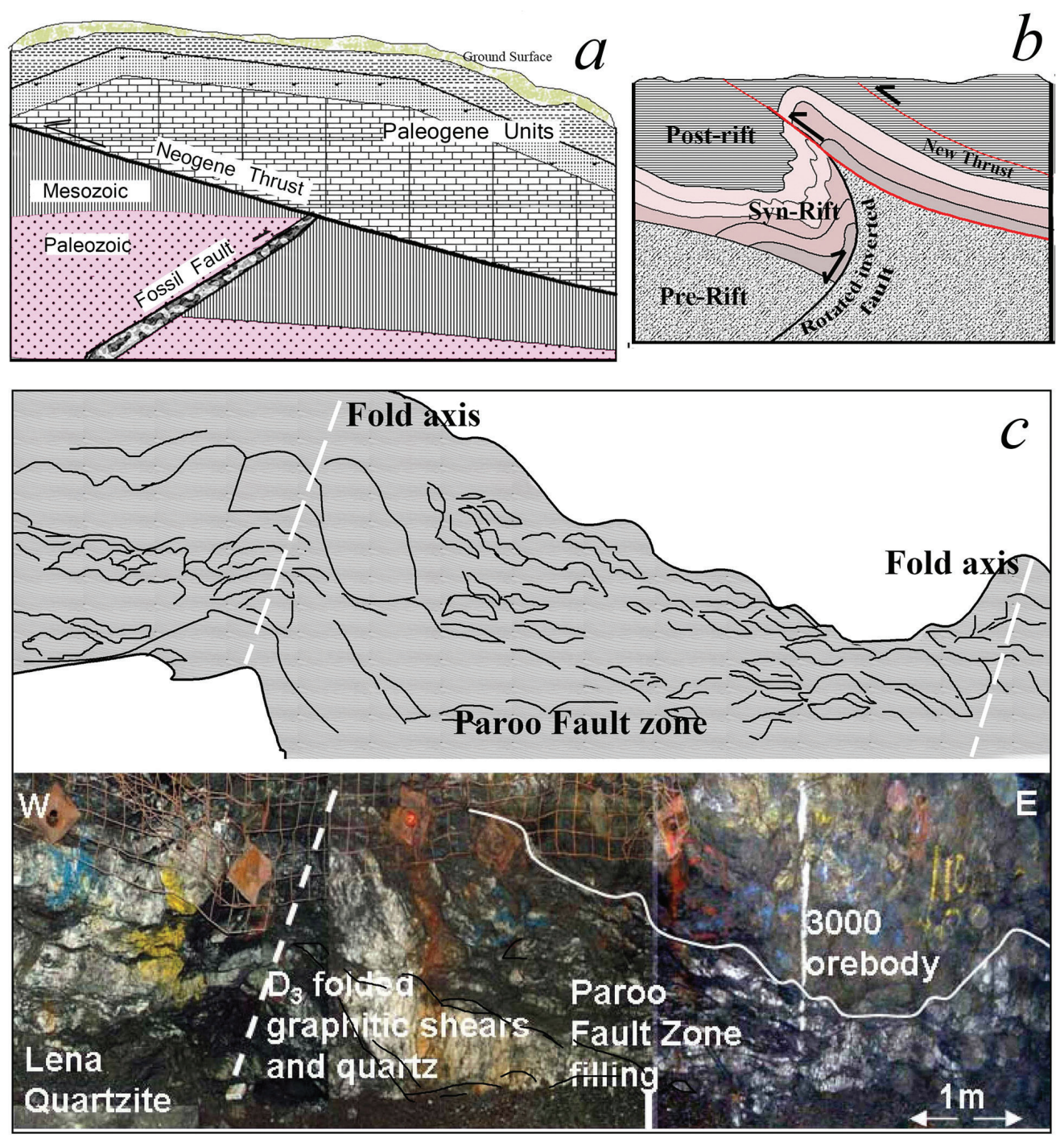

Fig. 2. Criteria for distinguishing fossil faults: $a$ ) old fault zone covered by a younger fault block; $b$ ) rotation of a fault zone, specifically in inverted terranes, that leads to change in dip direction of a portion of the fault and, sometimes, to its activation as a new fault zone (after Grocott and McCaffrey, 2017); c) folding of a fault zone shown as a sketch (up) with original photograph (down) taken from Long (2010), with kind permission from R.D. Long. 
Mohajjel and Houshmand, 2016) are good evidence of a fossil fault. In inverted terranes, some original normal faults become gradually steeper during inversion, until they cannot slip as a reverse fault due to mechanical difficulties (e.g., Coward, 1994). Some of these faults ultimately become inactive and then turn into fossil fault zones, but it is possible that some of them rotate passively and partially incorporate in the newly formed post-inversion faults (e.g., Grocott and McCaffrey, 2017; Fig. 2b).

The Hasanakdar Fault in the south Central Alborz is an originally normal fault that was inverted dur- ing the early Cimmerian phase in the Late Triassic (Ehteshami-Moinabadi et al., 2012; Fig. 3). Former studies show that this fault is a high-angle, southdipping inverted fault with a defined outcrop to the east of the Karaj Valley, showing evidence of ductile deformation, including foliation, S-C fabric, elongated quartz grains, etc. (Fig. $3 b-d$ ). However, to the west of the Karaj Valley, the fault is covered by the Cenozoic Thrust (TF) (Fig. 3a,e). Based on fieldwork, it has been suggested that the Hasanakdar Fault zone has rotated passively and incorporated partially into the TF fault zone (Fig. 3f). A more detailed geological back-


Fig. 3. Hasanakdar Fault, a fossil, partially rotated, inverted fault in Central Alborz. a) Local geologic map showing the Hasanakdar Fault (after Ehteshami-Moinabadi, 2017); b) Photograph of minor reverse faults in the Hasanakdar fault zone that have thrust Cambrian to Ordovician rocks from the south over the Permian rocks to the north. Stereogram after Ehteshami-Moinabadi et al. (2012); c) Southeast-dipping foliation in the Hasanakdar shear zone; d) Microphotograph of sheared rocks in the fault zone with ductile structures including elongated quartz grains along foliation, S-C fabric, and evidence of post-tectonic fabric changes; $e$ ) Thrust fault in the Permian rocks (TF in $a$ ) to the west of the Karaj Valley, which is interpreted as going inside the rotated portion of the Hasanakdar fault zone; f) Rotation of the Hasanakdar fault zone from a south-dipping high-angle fault to a shallow northeastdipping fault in the west parts of the Karaj Valley. 
ground of the area is given by Ehteshami-Moinabadi et al. (2012) and Ehteshami-Moinabadi (2017).

\section{APPLICATION OF FOSSIL FAULT STUDIES}

Convergent plate margins characterized by subduction erosion are fundamentally different from those characterized by accretion (Vannucchi et al., 2009). Since the early 1970s, seismic profiles, deep-sea drilling programs, and field studies on fossil subduction complexes have led to the development of the accretionary prism model (e.g., Karig, 1974; Seely et al., 1974; Karig and Sharman, 1975; Vannucchi et al., 2009). That was an early indirect application of fossil fault studies in the development of plate boundary evolution models. From an overall perspective, all studies devoted to mylonitic fault zones are in the domain of fossil fault studies. However, to obtain a sensible goal, it is needed to classify the usages of fossil fault studies in finer branches. Fossil fault studies may be applicable to the following subjects or classes: investigation on seismic faulting, analog models of active faults, metal ore deposits, paleo-path and fluid migration, and de- formation mechanism and fault migration along-strike and down-dip.

\section{Fossil faults and investigations on seismic faulting}

The study of fossil fault zones has opened new ways of understanding the details of friction and the way strain energy is partitioned at the source between seismic wave generation and the energy dissipated into fracture energy, heat, etc. (Vannucchi et al., 2009). Implosion brecciation is a process along seismic faults occurring due to sudden creation of void space and fluid-pressure differentials at dilational fault jogs during earthquake rupture (Fig. 4; Sibson, 1986). Examples of implosion brecciation within a dilational jog have been reported from a fossil thrust in Japan (Ujiie et al., 2007) and a fossil Precambrian shear zone that was reactivated later as a seismic fault in Norway (Swensson, 1990). Pseudotachylite is a cohesive glassy or very fine-grained fault-rock (Passchier and Trouw, 2005). It is the product of seismic heating along faults due to friction that leads to partial and local melting of rocks. Examples of fossil pseudotachylites have been

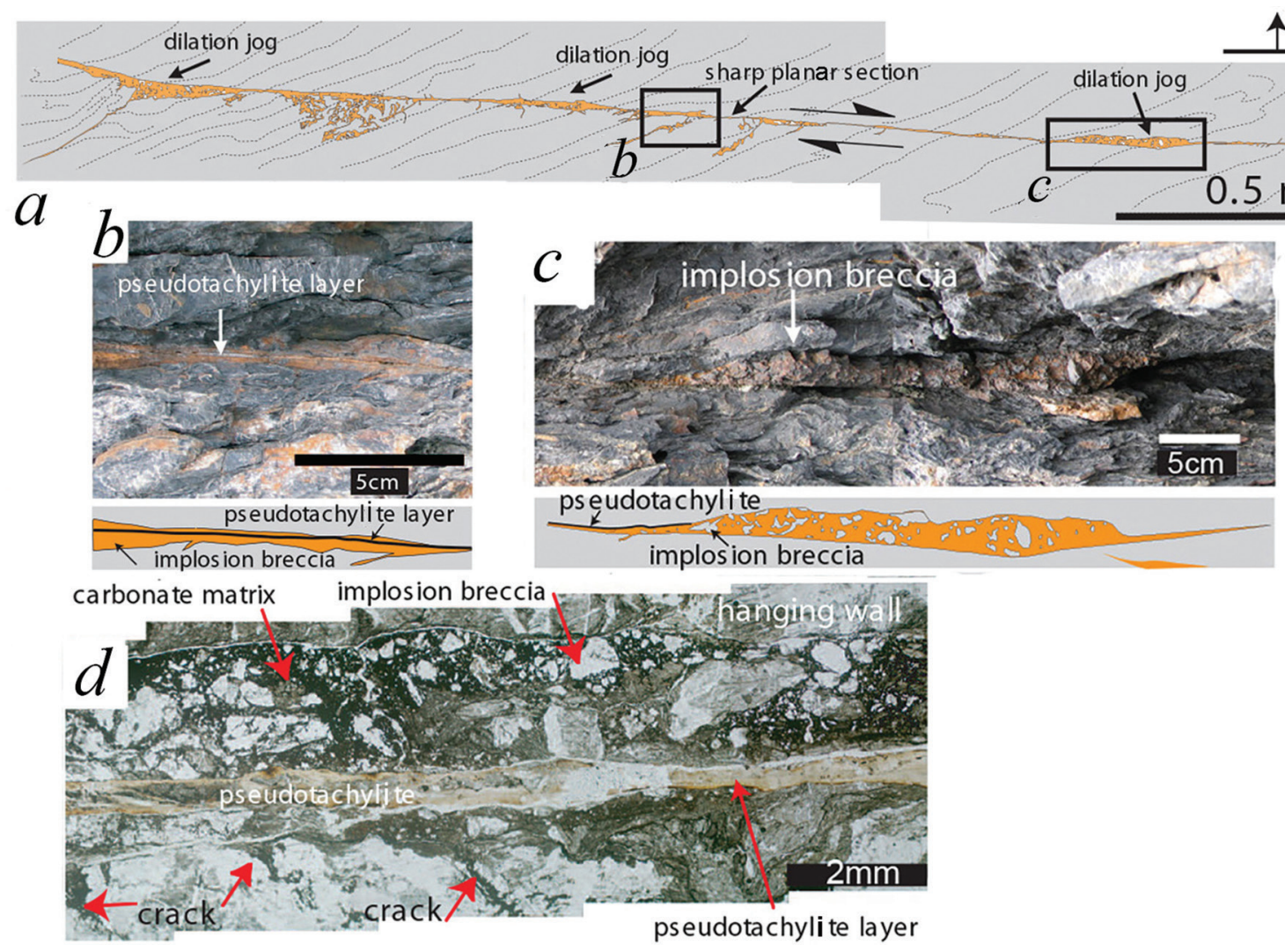

Fig. 4. Sketch and photographs of a fossil thrust fault from the Shimanto accretionary complex, Japan, modified from Okamoto et al. (2006) with kind permission from G. Kimura. a) Sketch of the fault. Outcrops are oblique to the slip direction. Note that the fault is composed of two parts: sharp planar sections and dilation jogs; $b$ ) Outcrop of a slipped part with pseudotachylite layer; $c$ ) Outcrop of dilation jog showing implosion breccias; $d$ ) Photomicrograph of the slipped part with pseudotachylite and implosion breccia, in which the translucent fault core is bounded by cataclasite-like breccia in the dark carbonate matrix. 
reported from the Cretaceous-Tertiary Shimanto Belt in Japan (Fig. 4; Ikesawa et al., 2003; Okamoto et al., 2006), the Alpine Belt in Croatia (Andersen and Austrheim, 2006), the Tananao Metamorphic Complex, Taiwan (Chu et al., 2012), and elsewhere. In fact, many pseudotachylites are fossil seismic fault rocks (Lin, 2008). Various aspects of pseudotachylites and researches on seismogenic friction were discussed in a special issue of Tectonophysics (Ferré et al., 2005). Acoustic fluidization is a process that allows fractured rock mass to behave like a fluid when acoustic waves travel through the rock, causing the fractured pieces to vibrate. Once the vibrations stop, a temporary reduction in friction occurs by reducing the confining pressure through a mechanism known as acoustic fluidization. It is also assumed to explain earthquake remote triggering (Melosh, 1979; Giacco et al., 2015). The product of this process may be preserved as fluidized cataclasites in fossil fault rocks (Rowe et al., 2005; Vannucchi et al., 2009; Yamaguchi et al., 2014). Another mechanism may be active in seismic depth, including pressure-solution and pressurizationdepressurization processes that may be found in fossil seismic faults. Vannucchi et al. (2009) described large fluid pressure variations during the seismic cycle and the role of a temperature-dependent change in the insitu fluid at the onset of seismogenesis by studying a fossil megathrust in the Northern Apennines of Italy.

\section{Fossil faults as analogs of active faulting}

Based on the tectonic setting of fossil faults at their final activity time span, they can be studied as analogous natural models to modern faults in similar active tectonic settings. For example, Rovelli et al. (2002) analyzed and reported the effects of trapped energy of seismic waves inside an inactive Pliocene fault zone in the Nocera Umbra, Central Italy. The trapping effect of fault zones has further been investigated by other researchers (e.g., Lewis et al., 2005). Lizurek et al. (2015) investigated a mining-induced earthquake in Polkowice Town near the Rudna mine, Poland. Based on the seismic analysis, along with macroseismic survey and observed effects from the destroyed part of the mining panel, they found that the mechanism of the event was complex rupture initiated as thrust faulting on an inactive tectonic normal fault zone.

\section{Fossil faults: ancient and modern paths for fluid migration}

Some faults can act as pathways for fluid migration, so they are important geological structures for fluid, energy, and solute transport (López and Smith, 1995). In a fault core and damage zone model of fault architecture, the fault core is considered as an across-fault flow barrier, while the damage zone is a fault conduit (Caine et al., 1996; Faulkner et al., 2010). Rocks from the fault core are commonly rich in phyllosilicates, which typically have low permeability, and only form barriers to flow if they are continuous throughout the fault plane (Faulkner and Rutter, 2001). Faults can be a fluid-migration pathway for water, hydrocarbons, etc. (Jiang et al., 1997; Boles et al., 2004; Faulkner et al., 2010). On the basis of the relationship between mineralization as high fluid flux indicator, static stress changes, fault triggering, and fluid flow in two mineralized Archean fault systems in Australia, Micklethwaite and Cox (2006) concluded that fluid flow through mid-crustal fault systems in crystalline rocks is spatially localized in regions where repeated clusters of aftershocks cause permeability enhancement. In other words, large aftershocks or subsequent triggered earthquakes can exert a strong control on where the highest fluid fluxes occur through small-event aftershock fault networks. Roberts (1991) assessed the structural control of fluid migration through a fossil thrust fault in the sub-Alpine foreland thrust belt of France. Meneghini et al. (2007) studied the deformation mechanisms associated with fluid migration across a fossil accretion-related fault zone in the Northern Apennines, Italy. By detailed analysis of different generations of syn-tectonic veins, they found and analyzed three hydro-fracturing vein systems that exhibit high-porosity and high-permeability channels observed along décollements in modern accretionary prisms (Meneghini et al., 2007).

Ritter et al. (2005) studied electrical conductivity images of active and fossil fault zones by magnetotelluric investigation. Based on the similarity between fault-zone conductors of active and inactive faults, they explained that meteoric waters enter the fault zone. However, their investigation on a high dip angle large fossil shear zone in Namibia showed that the shear zone has a high, anisotropic conductivity, which is attributed to graphitic enrichment along former shear planes. They concluded that graphite is stable over very long time spans, and thus fault zones may remain conductive for a long time after activity ceases (Ritter et al., 2005). Vannucchi et al. (2010) reported their observations on fluid flow along and across a Tertiary fossil fault in the Northern Apennines, Italy. They defined three levels of fluid flow. Deep, intermediate, and shallow levels are respectively characterized by discrete deformation events on shear faults offset by dilational jogs, repeated crack-and-seal events, and quasicontinuous deformation without vein formation.

By stable isotope and geochemical studies on a Tertiary normal shear zone in Basin and Range of Utah, Barnett et al. (1996) concluded that the fluid flow responsible for the isotopic alteration was episodic, of short duration, and possibly related to discrete seismic events. This observation supports a model of alternating fluid flow and permeability sealing related to hydrothermal deposition within fault zones. Studies on a large prehistoric landslide in the Himalayan Mountains of Nepal (i.e., Tsergo Ri) have shown that seeping glacier melt and precipitation waters into pre- 
existing structures of ore-mineralized zones, mylonitic rocks and pseudotachylite horizons destabilized one of the largest terrestrial landslides in the High Himalayan crystalline rocks in Langtang, Nepal (Weidinger et al., 1996, 2002; Schramm et al., 1998; Takagi et al., 2007).

\section{Fossil faults and metal ore deposits}

Major fault zones can directly or indirectly contribute to the formation of metal ore deposits. Sometimes, the fossil fault zones themselves are the host of ore mineralizations or have provided paths for hydrothermal fluids in the past (e.g., contact metamorphic deposits - Sawkins, 1990; Emsbo, 2009; and many other riftrelated deposits) or have structurally controlled the ore mineralization while active (e.g., Taupo Volcanic Zone, New Zealand - Krupp and Seward 1987; Philippine fault zone - Carranza and Hale, 2002; Cloos and Sapiie, 2013). Fossil fault zones may be the host for a variety of metal deposits including:

1) exoskarn or replacement deposits in limestonebearing fault zones near source intrusive rocks (e.g., Meinert et al., 1980; Einaudi and Burt, 1982);

2) mesothermal gold deposits in shear zones (e.g., Dodge and Loyd, 1984; Nesbitt et al., 1986; Sibson, 1986; Robert et al., 1995; Craw et al., 1999; Heidari et al., 2006);
3) some epithermal precious metal deposits such as Comstock Lode (Sawkins, 1990);

4) gold deposits related to low-angle detachment faults (Fig. 5; Sawkins, 1990; Long, 1992; Carillo and Huyck, 1997; Marchev et al., 2004);

5) examples of Cyprus-type VMS, such as most of the deposits in the Newfoundland ophiolites (Sawkins, 1990);

6) occurrence of $\mathrm{Cu}, \mathrm{Ni}, \mathrm{Co}$, and Fe sulfides and arsenides along fossil fault zones within serpentinized harzburgite in the Limmasol Forest area of the Troodos ophiolite (Panayiotou, 1980);

7) relationship between kimberlites and fossil transform faults (Mitchell and Garson, 1981).

\section{Fossil fault studies for understanding deformation mechanisms, along-strike and down-dip fault migration}

Faults evolve on different scales of time and length. The kinematics of faulting and fault geometry are as important as grain-scale deformation mechanisms in determining the rheology of faults in the lithosphere (Handy et al., 2007). Many studies on microstructures and deformation of mineral grains in ductile shear zones during last several decades are based on sections and samples from fossil exhumed ductile fault zones and mylonites (e.g., Bell and Etheridge, 1976; Berthé

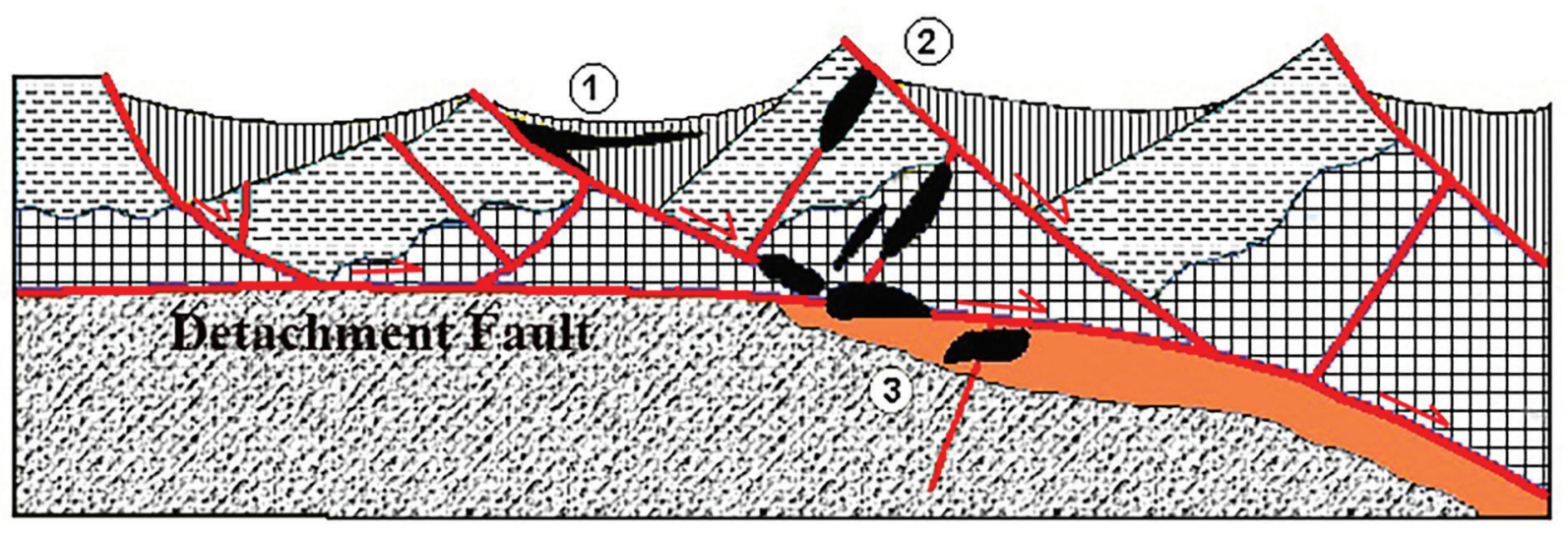

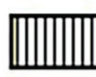
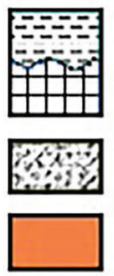

\section{Syn-tectonic sediments}

Upper-plate sedimentary and igneous rocks

Metamorphic rocks of

lower plate

Mylonite
Mineralized zones

Fault

Cu-Fe-Pb-Zn-Ag-Au

replacement and veins

(2)

Barite-Fluorite veins

(3) Mn beds and veins

Fig. 5. Schematic diagram showing the structural position of detachment fault-related polymetallic mineralization, (Mn)-baritefluorite veins, and lacustrine manganese mineralization in detachment-faulted terrane in a core-complex setting. Modified after Long (1992), with kind permission from K.L. Long. 
et al., 1979; White et al., 1980; Gapais and White, 1981; Burg et al., 1984; Passchier, 1984; Simpson, 1985; Jessell, 1987; Knipe, 1989; Pryer, 1993; Antonellini et al., 1994; Grujic et al., 1996; Brown and Solar, 1998; Stipp et al., 2002; Warren and Hirth, 2006; Skemer et al., 2009; Cao et al., 2010; Hadizadeh et al., 2012; Piazolo et al., 2012). Exhumation of fossil faults from different paleodepths provides opportunity for the study of fault mechanisms and propagation along-strike and down-dip (Furlong et al., 2007). A fossil transpressional fault zone in the Tertiary European Alps indicates that localization in the upper crust has involved fracturing and cataclasis, while in the lower crust it has included buckling and mylonite shearing along anisotropic compositional banding and schistosity (Furlong et al., 2007). Fault migration occurs when a main fault zone cannot be reactivated and fresh fault surfaces develop in the footwall or hanging wall of the main fault with linkage (Stewart and Hancock, 1991). One consequence of the migration of fault zones is the inactivation and then fossilization of older fault zones. During positive tectonic inversion, some of the original normal faults are not reactivated, but they represent important mechanical discontinuities generating stress concentration and buttressing effects that can localize the development of successive thrust ramps or new footwall shortcuts (e.g., Coward et al., 1991; Tavarnelli, 1996; Erickson et al., 2001; Scisciani et al., 2001; Scisciani, 2009; EhteshamiMoinabadi, 2014). Sometimes, the behavior of a fossil fault can passively change and play the role of a zone of weakness for new thrust development just on the opposite side of the original vergence of the fault.

\section{DISCUSSION}

Fossil faults are permanently inactive fault zones, preserved and recognized in the geological records of an area by major brittle, semi-brittle or mylonitic fault rocks. Geologically, the fossil faults have no possibility of whole-length reactivation, while the inactive faults can reactivate due to change of regional stress regime or regional strain rate. In other words, the whole-length reactivation of very old fossil fault zones that, for example, have been passively folded or metamorphosed is under question. However, they can sometimes passively rotate and partially incorporate in a new fault (Figs 2, 3). In no period of modern structural geologic studies have fossil faults been considered as the origin and destination subject of investigations. However, the interconnectedness of different objects in geological structures, very long-term (order of billions of years) consistency of simple but important rules on Earth, stress, strain and deformation mechanisms, rheology and rock mechanics has provided an opportunity for structural geologists to apply Charles Lyell's law "the present is the key for the past" (Blundell and Scott, 1998; Mathieson, 2002). Fossil faults are a major source of information about past geological processes that were active at some depth in Earth's lithosphere, and also provide an opportunity for proposing and predicting the future in structural geology. Major applications of studies on fossil faults have been categorized in Table 1. It also shows the subsidiary subjects in each topic and some examples form the available literature. Some subsidiary subjects are relatively new topics and seem to attract more attention in the future, e.g., partitioning of strain energy at seismic source, acoustic fluidization, the trapping effect of fossil faults for seismic energy, fault zone and clay mineral studies based on fossil faults, faulting and deformation mechanisms at different depths, and fault zone migration. Other topics have a long history of research that still continues, such as host rocks of ore mineralization and ductile microstructures in mylonites. Ultimately, it is possible that fossil faults will attract more attention for studying geophysical properties and synchronous integrated researches on various subjects related to major fault zones.

\section{CONCLUSION}

Fossil faults are permanently inactive fault zones, preserved and recognized in the geological records of an area by major brittle, semi-brittle or mylonitic fault rocks, showing a significant width and displacement. Investigations on fossil faults and their applications may be categorized as seismic faulting, analog models of active faults, metal ore deposits, paleo-path and fluid migration, and deformation mechanism and fault migration along-strike and down-dip. In no period of modern structural geology studies have fossil faults been considered as the origin and subject of investigations. However, studies on some aspects of structural geology based on exposed fossil ductile fault zones go back to the early 1970s, or even earlier. Fossil faults are a major source of information about past geological processes that have been active at some depth in the lithosphere, and also provide an opportunity for predicting the future in structural geology. Some subsidiary subjects are relatively new topics and seem to attract more attention in the future, e.g. partitioning of strain energy at seismic source, acoustic fluidization, the trapping effect of fossil faults for seismic energy, fault zone and clay minerals, etc. Also, it is possible that fossil faults may attract more attention for multidisciplinary researches and examining geophysical properties of fault zones in the near future.

\section{Acknowledgements}

Anonymous reviewers are greatly acknowledged for their comments, which helped improve the manuscript. Many thanks to Dr R.D. Long (James Cook University, Queensland, Australia) and Profs G. Kimura (Tokyo University, Japan) and K.L. Long (USGS) for giving their permission to re-use their figures. 
Table 1

Major applications and subsidiary fields of research on fossil faults

\begin{tabular}{|c|c|c|}
\hline Major topics & Subsidiary topics & Sources \\
\hline \multirow[t]{5}{*}{$\begin{array}{l}\text { Investigations on } \\
\text { seismic faulting }\end{array}$} & $\begin{array}{l}\text { Partitioning of strain energy at } \\
\text { source between wave generation, } \\
\text { fracture generation, heat, etc. }\end{array}$ & Vannucchi et al. (2009) \\
\hline & Implosion brecciation & Swensson (1990); Ujiie et al. (2007) \\
\hline & $\begin{array}{l}\text { Pseudotachylite and other seismo- } \\
\text { genic fault rocks }\end{array}$ & $\begin{array}{l}\text { Ikesawa et al. (2003); Andersen and Austrheim (2006); } \\
\text { Okamoto et al. (2006); Chu et al. (2012) }\end{array}$ \\
\hline & Acoustic fluidization & $\begin{array}{l}\text { Rowe et al. (2005); Vannucchi et al. (2009); Yamaguchi et al. } \\
\text { (2014) }\end{array}$ \\
\hline & $\begin{array}{l}\text { Pressure solution/fluid pressure } \\
\text { variation and seismic cycle }\end{array}$ & Vannucchi et al. (2009) \\
\hline \multirow[t]{2}{*}{$\begin{array}{l}\text { Analogs of active } \\
\text { faulting }\end{array}$} & $\begin{array}{l}\text { Trapping seismic energy in inactive/ } \\
\text { fossil faults }\end{array}$ & Rovelli et al. (2002); Lewis et al. (2005) \\
\hline & $\begin{array}{l}\text { Mining and seismic activation of } \\
\text { inactive/fossil fault }\end{array}$ & Lizurek et al. (2015) \\
\hline \multirow{5}{*}{$\begin{array}{l}\text { Ancient and mod- } \\
\text { ern paths for fluid } \\
\text { migration }\end{array}$} & Core zone/damage zone & Caine et al. (1996); Faulkner et al. (2010) \\
\hline & Clay minerals in fault zones & Wintsch et al. (1995); Faulkner and Rutter (2001) \\
\hline & $\begin{array}{l}\text { Complex relationships among vari- } \\
\text { ous parameters in fault zones }\end{array}$ & Micklethwaite and Cox (2006) \\
\hline & Fluid migration in fault zones & $\begin{array}{l}\text { Roberts (1991); Jiang et al. (1997); Boles et al. (2004); } \\
\text { Meneghini et al. (2007); Faulkner et al. (2010) }\end{array}$ \\
\hline & $\begin{array}{l}\text { Geophysical properties of fault } \\
\text { zones }\end{array}$ & $\begin{array}{l}\text { Ledo et al. (2002); Ritter et al. (2003); Ritter et al. (2005); } \\
\text { Smirnov and Pedersen (2009) }\end{array}$ \\
\hline \multirow[t]{3}{*}{ Metal ore deposits } & As host of ore mineralization & $\begin{array}{l}\text { Robertson (1978); Einaudi and Burt (1982); Sawkins (1990); } \\
\text { Long (1992); Robert et al. (1995); Carillo and Huyck (1997); } \\
\text { Craw et al. (1999); Marchev et al. (2004) }\end{array}$ \\
\hline & $\begin{array}{l}\text { Structural control of ore } \\
\text { mineralization }\end{array}$ & $\begin{array}{l}\text { Krupp and Seward (1987); Carranza and Hale (2002); Cloos } \\
\text { and Sapiie (2013) }\end{array}$ \\
\hline & Pathway for hydrothermal fluids & Sawkins (1990); Oliver and Bons (2001); Emsbo (2009) \\
\hline \multirow[t]{3}{*}{$\begin{array}{l}\text { Deformation } \\
\text { mechanisms, along- } \\
\text { strike/down-dip } \\
\text { fault migration }\end{array}$} & $\begin{array}{l}\text { Microstructures in ductile shear } \\
\text { zones }\end{array}$ & $\begin{array}{l}\text { Bell and Etheridge (1976); Berthé et al. (1979); White et al. } \\
\text { (1980); Burg et al. (1984); Passchier (1984); Simpson (1985); } \\
\text { Knipe (1989); Grujic et al. (1996); Brown and Solar (1998); } \\
\text { Stipp et al. (2002); Warren and Hirth (2006); Skemer et al. } \\
\text { (2009); Piazolo et al. (2012) }\end{array}$ \\
\hline & $\begin{array}{l}\text { Faulting and deformation mecha- } \\
\text { nisms at different depths }\end{array}$ & Furlong et al. (2007); Vannucchi et al. (2010) \\
\hline & $\begin{array}{l}\text { Along-strike/down-dip fault } \\
\text { migration }\end{array}$ & $\begin{array}{l}\text { Scisciani et al. (2001); Leeder et al. (2008); Ehteshami- } \\
\text { Moinabadi (2013) }\end{array}$ \\
\hline
\end{tabular}

\section{REFERENCES}

Andersen, T.B., Austrheim, H. 2006. Fossil earthquakes recorded by pseudotachylites in mantle peridotite from the Alpine subduction complex of Corsica. Earth and Planetary Science Letters 242 (1), 58-72.

Antonellini, M.A., Aydin, A., Pollard, D.D. 1994. Microstructure of deformation bands in porous sandstones at Arches
National Park, Utah. Journal of Structural Geology 16 (7), 941-959.

Barnett, D.E., Bowman, J.R., Bromley, C., Cady, C. 1996. Kinetically limited isotope exchange in a shallow level normal fault, Mineral Mountains, Utah. Journal of Geophysical Research: Solid Earth 101 (B1), 673-685. 
Bell, T.H., Etheridge, M.A. 1976. The deformation and recrystallization of quartz in a mylonite zone, central Australia. Tectonophysics 32 (3-4), 235-267.

Berthé, D., Choukroune P., Jégouzo, P. 1979. Orthogneiss, mylonite and non-coaxial deformation of granites: the example of the South Armorican Shear Zone. Journal of Structural Geology 1 (1), 31-42.

Blundell, D.J., Scott, A.C. 1998. Lyell: the Past is the Key to the Present. Geological Society, London, Special Publications Series 143, $368 \mathrm{pp}$.

Boles, J.R., Eichhubl, P., Garven, G., Chen, J. 2004. Evolution of a hydrocarbon migration pathway along basin-bounding faults: Evidence from fault cement. American Association of Petroleum Geologists Bulletin 88 (7), 947-970.

Brown, M., Solar, G.S. 1998. Granite ascent and emplacement during contractional deformation in convergent orogens. Journal of Structural Geology 20 (9), 1365-1393.

Burg, J.P., Brunel, M., Gapais, D., Chen, G.M., Liu, G.H. 1984. Deformation of leucogranites of the crystalline Main Central Sheet in southern Tibet (China). Journal of Structural Geology 6 (5), 535-542.

Caine, J.S., Evans, J.P., Forster, C.B. 1996. Fault zone architecture and permeability structure. Geology 24 (11), 1025-1028.

Cao, S., Liu, J., Leiss, B. 2010. Orientation-related deformation mechanisms of naturally deformed amphibole in amphibolite mylonites from the Diancang Shan, SW Yunnan, China. Journal of Structural Geology 32 (5), 606-622.

Carrillo, A., Huyck, H. 1997. A genetic model for the Los Uvares gold deposit, Baja California Sur, Mexico. Geofísica Internacional 36 (2) (http://www.redalyc.org/articulo. oa?id=56836204).

Carranza, E.J.M., Hale, M. 2002. Spatial relationships of porphyry copper deposits with strike-slip fault discontinuities and plutons, Benguet, Philippines: Where are porphyry copper deposits spatially localized? A case study in Benguet province, Philippines. Natural Resources Research 11 (1), 45-59.

Chu, H.T., Hwang, S.L., Shen, P., Yui, T.F. 2012. Pseudotachylite in the Tananao Metamorphic Complex, Taiwan: Occurrence and dynamic phase changes of fossil earthquakes. Tectonophysics 581, 62-75.

Cloos, M., Sapiie, B. 2013. Porphyry copper deposits: strikeslip faulting and throttling cupolas. International Geology Review 55 (1), 43-65.

Coward, M.P. 1994. Inversion tectonics. In: Hancock, P.L. (Ed.), Continental Deformation. Pergamon Press, 289-304.

Coward, M.P., Gillcrist, R., Trudgill, B. 1991. Extensional structures and their tectonic inversion in the Western Alps. Geological Society, London, Special Publications Series 56, $260 \mathrm{pp}$.

Craw, D., Windle, S.J., Angus, P.V. 1999. Gold mineralization without quartz veins in a ductile-brittle shear zone, Macraes Mine, Otago Schist, New Zealand. Mineralium Deposita 34 (4), 382-394.

Dodge, F.C., Loyd, R.C. 1984. Gold deposits of the western Sierra Nevada, field trip guide. US Geological Survey OpenFile Report 84-169, 30 pp.

Ehteshami-Moinabadi, M. 2013. Post-Triassic deformation analysis of the zone between Mosha and Taleqan faults in the Central Alborz. PhD thesis, Tarbiat Modares University, $124 \mathrm{pp}$.

Ehteshami-Moinabadi, M. 2014. Fault zone migration by footwall shortcut and recumbent folding along an inverted fault: example from the Mosha Fault, Central Alborz, Northern Iran. Canadian Journal of Earth Sciences 51 (9), 825-836.

Ehteshami-Moinabadi, M. 2017. Post-Triassic normal faulting and extensional structures in Central Alborz, Northern Iran. Geopersia 7 (1), 85-102.
Ehteshami-Moinabadi, M.E., Yassaghi, A. 2007. Geometry and kinematics of the Mosha Fault, south central Alborz Range, Iran: An example of basement involved thrusting. Journal of Asian Earth Sciences 29 (5), 928-938.

Ehteshami-Moinabadi, M., Yassaghi, A. 2013. Oblique inversion, a model for Oligocene-Miocene tectonics of south Central Alborz. Researches in Earth Sciences 4 (15), 32-50 (in Persian, with English abstract).

Ehteshami-Moinabadi, M., Yassaghi, A., Amini, A. 2012. Mesozoic basin inversion in Central Alborz, evidence from the evolution of Taleqan-Gajereh-Lar paleograben. Geopersia 2 (2), 43-63.

Einaudi, M.T., Burt, D.M. 1982. Introduction; terminology, classification, and composition of skarn deposits. Economic geology 77 (4), 745-754.

Emsbo, P. 2009. Geologic criteria for the assessment of sedimentary exhalative (Sedex) $\mathrm{Zn}-\mathrm{Pb}-\mathrm{Ag}$ deposits. US Geological Survey Open-File Report 1209, 21 pp.

Erickson, S.G., Strayer, L.M., Suppe, J. 2001. Mechanics of extension and inversion in the hanging walls of listric normal faults. Journal of Geophysical Research: Solid Earth 106 (B11), 26655-26670.

Faulkner, D.R., Jackson, C.A.L., Lunn, R.J., Schlische, R.W., Shipton, Z.K., Wibberley, C.A.J., Withjack, M.O. 2010. A review of recent developments concerning the structure, mechanics and fluid flow properties of fault zones. Journal of Structural Geology 32 (11), 1557-1575.

Faulkner, D.R., Rutter, E.H. 2001. Can the maintenance of overpressured fluids in large strike-slip fault zones explain their apparent weakness?. Geology 29 (6), 503-506.

Ferré, E.C., Allen, J.L., Lin, A. 2005. Pseudotachylites and seismogenic friction: an introduction to current research. Tectonophysics 402 (1), 1-2.

Furlong, K., Beroza, G.C., Brun, J.P., Cowie, P.A., Handy, M.R., Mooney, W.D., Taymaz, T., Teyssier, C., Vauchez, A., Wernicke, B. 2007. Nucleation and growth of fault systems. In: Handy, M., Hirth, G., Hovius, N. (Eds), Tectonic faults: Agents of change on a dynamic Earth. MIT Press, Cambridge, 78-98.

Gapais, D., White, S.H. 1982. Ductile shear bands in a naturally deformed quartzite. Texture, Stress, and Microstructure 5 (1), 1-17.

Gerald, J.F., Stünitz, H. 1993. Deformation of granitoids at low metamorphic grade. I: Reactions and grain size reduction. Tectonophysics 221 (3), 269-297.

Giacco, F., Saggese, L., de Arcangelis, L., Lippiello, E., Ciamarra, M.P. 2015. Dynamic weakening by acoustic fluidization during stick-slip motion. Physical review letters 115, doi:10.1103/PhysRevLett.115.128001.

Grocott, J., McCaffrey, K.J. 2017. Basin evolution and destruction in an Early Proterozoic continental margin: the Rinkian fold-thrust belt of central West Greenland. Journal of the Geological Society 174 (3), 453-467.

Grujic, D., Casey, M., Davidson, C., Hollister, L.S., Kündig, R., Pavlis, T., Schmid, S. 1996. Ductile extrusion of the Higher Himalayan Crystalline in Bhutan: evidence from quartz microfabrics. Tectonophysics 260 (1), 21-43.

Hadizadeh, J., Mittempergher, S., Gratier, J.P., Renard, F., Di Toro, G., Richard, J., Babaie, H.A. 2012. A microstructural study of fault rocks from the SAFOD: Implications for the deformation mechanisms and strength of the creeping segment of the San Andreas Fault. Journal of Structural Geology 42, 246-260.

Handy, M.R., Hirth, G., Bürgmann, R. 2007. Continental fault structure and rheology from the frictional-to-viscous transition downward. In: Handy, M.R., Hirth, G., Hovius, N. (Eds), Tectonic faults: agents of change on a dynamic Earth. MIT Press, Cambridge, 139-181. 
Heidari, S.M., Mossavi Makooi, S.A., Mirzakhanian, M., Rasoli, F., Ghaderi, M., Abadi, A.R. 2006. A review of tectonomagmatic evolution and gold metallogeny in the inner parts of Zagros orogeny: a tectonic model for the major gold deposits, western Iran. Eurasian Mining 1, 3-20.

Ikesawa, E., Sakaguchi, A., Kimura, G. 2003. Pseudotachylite from an ancient accretionary complex: Evidence for melt generation during seismic slip along a master decollement?. Geology 31 (7), 637-640.

Jackson, J. 1999. Fault death: a perspective from actively deforming regions. Journal of Structural Geology 21 (8), 1003-1010.

Jessell, M.W. 1987. Grain-boundary migration microstructures in a naturally deformed quartzite. Journal of Structural Geology 9 (8), 1007-1014.

Jiang, Z., Oliver, N.H., Barr, T.D., Power, W.L., Ord, A. 1997. Numerical modeling of fault-controlled fluid flow in the genesis of tin deposits of the Malage ore field, Gejiu mining district, China. Economic Geology 92 (2), 228-247.

Karig, D.E. 1974. Evolution of arc systems in the western Pacific. Annual Review of Earth and Planetary Sciences 2 (1), 51-75.

Karig, D.E., Sharman, G.F. 1975. Subduction and accretion in trenches. Geological Society of America Bulletin 86 (3), 377-389.

Knipe, R.J. 1989. Deformation mechanisms-recognition from natural tectonites. Journal of Structural Geology 11 (1-2), 127-146.

Krupp, R.E., Seward, T.M. 1987. The Rotokawa geothermal system, New Zealand; an active epithermal gold-depositing environment. Economic Geology 82 (5), 1109-1129.

Lacombe, O., Bellahsen, N. 2016. Thick-skinned tectonics and basement-involved fold-thrust belts: insights from selected Cenozoic orogens. Geological Magazine 153 (5-6), 763-810.

Ledo, J., Jones, A.G., Ferguson, I.J. 2002. Electromagnetic images of a strike-slip fault: The Tintina fault-Northern Canadian. Geophysical Research Letters 29 (8), 66-1-66-4.

Leeder, M.R., Mack, G.H., Brasier, A.T., Parrish, R.R., McIntosh, W.C., Andrews, J.E., Duermeijer, C.E. 2008. LatePliocene timing of Corinth (Greece) rift-margin fault migration. Earth and Planetary Science Letters 274 (1), 132-141.

Lewis, M.A., Peng, Z., Ben-Zion, Y., Vernon, F.L. 2005. Shallow seismic trapping structure in the San Jacinto fault zone near Anza, California. Geophysical Journal International 162 (3), 867-881.

Lin, A. 2008. Fossil earthquakes: The formation and preservation of pseudotachylites. Springer-Verlag, Berlin-Heidelberg, $348 \mathrm{pp}$.

Lizurek, G., Rudziński, Ł., Plesiewicz, B. 2015. Mining induced seismic event on an inactive fault. Acta Geophysica 63 (1), 176-200.

Long, K.L. 1992. Preliminary descriptive deposit model for detachment-fault-related mineralization. US Geological Survey Bulletin 2004, 52-62.

Long, R.D. 2010. The Paroo Fault and the Mount Isa copper orebodies; a revised structural and evolutionary model, $M t$ Isa, Queensland, Australia. PhD thesis, James Cook University, Queensland, Australia, $240 \mathrm{pp}$.

López, D.L., Smith, L. 1995. Fluid flow in fault zones: analysis of the interplay of convective circulation and topographically driven groundwater flow. Water Resources Research 31 (6), 1489-1503.

Marchev, P., Singer, B.S., Jelev, D., Hasson, S., Moritz, R., Bonev, N. 2004. The Ada Tepe deposit: a sediment-hosted, detachment fault-controlled, low-sulfidation gold deposit in the Eastern Rhodopes, SE Bulgaria. Swiss Bulletin of Mineralogy and Petrology 84 (1), 59-78.
Mathieson, E.L. 2002. The present is the key to the past is the key to the future. Proceedings of 98th Annual Meeting of the Geological Society of America, Abstracts (https://gsa. confex.com/gsa/2002CD/finalprogram/abstract_34786. htm).

Meigs, A., Krugh, W.C., Schiffman, C., Vergés, J., Ramos, V.A. 2006. Refolding of thin-skinned thrust sheets by active basement-involved thrust faults in the eastern Precordillera of western Argentina. Revista de la Asociación Geológica Argentina 61 (4), 589-603.

Meinert, L.D., Newberry, R.J., Einaudi, M.T. 1980. An overview of tungsten, copper, and zinc-bearing skarns in western North America. US Geological Survey Open-File Report 81-355, 303-327.

Melosh, H.J. 1979. Acoustic fluidization: A new geologic process?. Journal of Geophysical Research: Solid Earth 84 (B13), 7513-7520.

Meneghini, F., Marroni, M., Pandolfi, L. 2007. Fluid flow during accretion in sediment-dominated margins: Evidence of a high-permeability fossil fault zone from the Internal Ligurian accretionary units of the Northern Apennines, Italy. Journal of Structural Geology 29 (3), 515-529.

Micklethwaite, S., Cox, S.F. 2006. Progressive fault triggering and fluid flow in aftershock domains: Examples from mineralized Archaean fault systems. Earth and Planetary Science Letters 250 (1), 318-330.

Miller, M.G. 2003. Basement-involved thrust faulting in a thin-skinned fold-and-thrust belt, Death Valley, California, USA. Geology 31 (1), 31-34.

Mitchell, A.H.G., Garson, M.S. 1981. Mineral deposits and global tectonic settings. Academic Press, London-Sydney, $405 \mathrm{pp}$.

Mohajjel, M., Houshmand, S.M. 2016. Deformation and folding of mylonitic fabrics in Nowqan ductile shear zone: SW Golpaygan (Sanandaj-Sirjan Zone). Quaterly Journal of Geosciences 25 (100), 91-98 (in Persian, with English abstract).

Nesbitt, B.E., Murowchick, J.B., Muehlenbachs, K. 1986. Dual origins of lode gold deposits in the Canadian Cordillera. Geology 14 (6), 506-509.

Okamoto, S., Kimura, G., Takizawa, S., Yamaguchi H. 2006. Earthquake fault rock indicating a coupled lubrication mechanism. eEarth 1 (1), 23-28.

Oliver, N.H., Bons, P.D. 2001. Mechanisms of fluid flow and fluid-rock interaction in fossil metamorphic hydrothermal systems inferred from vein-wallrock patterns, geometry and microstructure. Geofluids 1 (2), 137-162.

Panayiotou, A. 1980. Cu-Ni-Co-Fe sulphide mineralization, Limassol Forest, Cyprus. Proceedings of the International Ophiolite Symposium, Nicosia (Cyprus), 1979.

Passchier, C.W. 1984. The generation of ductile and brittle shear bands in a low-angle mylonite zone. Journal of Structural Geology 6 (3), 273-281.

Passchier, C.W., Trouw, R.A. 2005. Microtectonics. SpringerVerlag, Berlin-Heidelberg, 289 pp.

Piazolo, S., Austrheim, H., Whitehouse M. 2012. Brittle-ductile microfabrics in naturally deformed zircon: Deformation mechanisms and consequences for $\mathrm{U}-\mathrm{Pb}$ dating. American Mineralogist 97 (10), 1544-1563.

Pryer, L.L. 1993. Microstructures in feldspars from a major crustal thrust zone: the Grenville Front, Ontario, Canada. Journal of Structural Geology 15 (1), 21-36.

Ritter, O., Hoffmann-Rothe, A., Bedrosian, P.A., Weckmann, U., Haak, V. 2005. Electrical conductivity images of active and fossil fault zones. Geological Society, London, Special Publications 245 (1), 165-186.

Ritter, O., Weckmann, U., Vietor, T., Haak, V. 2003. A magnetotelluric study of the Damara Belt in Namibia: 1. Re- 
gional scale conductivity anomalies. Physics of the Earth and Planetary Interiors 138 (2), 71-90.

Robert, F., Boullier, A.M., Firdaous, K. 1995. Gold-quartz veins in metamorphic terranes and their bearing on the role of fluids in faulting. Journal of Geophysical Research: Solid Earth 100 (B7), 12861-12879.

Roberts, G. 1991. Structural controls on fluid migration through the Rencurel thrust zone, Vercors, French sub-Alpine chains. Geological Society, London, Special Publications Series 59 (1), 245-262.

Robertson, A.H.F. 1978. Metallogenesis along a fossil oceanic fracture zone: Arakapas fault belt, Troodos Massif, Cyprus. Earth and Planetary Science Letters 41 (3), 317-329.

Rovelli, A., Caserta, A., Marra, F., Ruggiero, V. 2002. Can seismic waves be trapped inside an inactive fault zone? The case study of Nocera Umbra, central Italy. Bulletin of the Seismological Society of America 92 (6), 2217-2232.

Rowe, C.D., Moore, J.C., Meneghini, F., McKeirnan, A.W. 2005. Large-scale pseudotachylites and fluidized cataclasites from an ancient subduction thrust fault. Geology 33 (12), 937-940.

Sawkins, F.J. 1990. Metal deposits in relation to plate tectonics. Springer-Verlag, Berlin, 461 pp.

Schramm, J.M., Weidinger, J.T., Ibetsberger, H.J. 1998. Petrologic and structural controls on geomorphology of prehistoric Tsergo Ri slope failure, Langtang Himal, Nepal. Geomorphology 26 (1), 107-121.

Scisciani, V. 2009. Styles of positive inversion tectonics in the Central Apennines and in the Adriatic foreland: Implications for the evolution of the Apennine chain (Italy). Journal of Structural Geology 31 (11), 1276-1294.

Scisciani, V., Tavarnelli, E., Calamita, F. 2001. Styles of tectonic inversion within syn-orogenic basins: examples from the Central Apennines, Italy. Terra Nova 13 (5), 321-326.

Seely, D.R., Vail, P.R., Walton, G.G. 1974. Trench slope model. Proceedings of the $3^{\text {rd }}$ AAPG Convention, 333-351.

Sibson, R.H. 1986. Brecciation processes in fault zones: inferences from earthquake rupturing. Pure and Applied Geophysics 124 (1-2), 159-175.

Simpson, C. 1985. Deformation of granitic rocks across the brittle-ductile transition. Journal of Structural Geology 7 (5), 503-511.

Smirnov, M.Y., Pedersen, L.B. 2009. Magnetotelluric measurements across the Sorgenfrei-Tornquist Zone in southern Sweden and Denmark. Geophysical Journal International 176 (2), 443-456.

Skemer, P., Warren, J.M., Kelemen, P.B., Hirth, G. 2009 Microstructural and rheological evolution of a mantle shear zone. Journal of Petrology 51 (1-2), 43-53.

Stewart, I.S., Hancock, P.L. 1991. Scales of structural heterogeneity within neotectonic normal fault zones in the Aegean region. Journal of Structural Geology 13 (2), 191-204.

Stipp, M., Stünitz, H., Heilbronner, R., Schmid, S.M. 2002. The eastern Tonale fault zone: a 'natural laboratory' for crystal plastic deformation of quartz over a temperature range from 250 to $700^{\circ} \mathrm{C}$. Journal of Structural Geology 24 (12), 1861-1884.
Suppe, J., Wang, X., He, D., Liang, H. 2015. Large-scale thrusting along the northern margin of the Tibetan Plateau and the southwest Tarim basin: $230 \mathrm{~km}$ long active Hotian thrust sheet. Proceedings of the American Geophysical Union Fall Meeting, 2015, Abstracts.

Swensson, E. 1990. Cataclastic rocks along the Nesodden Fault, Oslo Region, Norway: a reactivated Precambrian shear zone. Tectonophysics 178 (1), 51-65.

Takagi, H., Arita, K., Danhara, T., Iwano, H. 2007. Timing of the Tsergo Ri landslide, Langtang Himal, determined by fission-track dating of pseudotachylite. Journal of Asian Earth Sciences 29 (2), 466-472.

Tavarnelli, E. 1996. The effects of pre-existing normal faults on thrust ramp development: an example from the Northern Apennines, Italy. Geologische Rundschau 85 (2), 363-371.

Ujiie, K., Yamaguchi, A., Kimura, G., Toh, S. 2007. Fluidization of granular material in a subduction thrust at seismogenic depths. Earth and Planetary Science Letters 259 (3), 307-318.

USGS. 2017. Earthquake glossary (https://earthquakes.usgs. gov/learn/glossary).

US NRC. 2017. Part 100-reactor site criteria (https://www. nrc.gov/reading-rm/doc-collections/cfr/part100/).

Vannucchi, P., Remitti, F., Bettelli, G., Boschi, C., Dallai, L. 2010. Fluid history related to the early Eocene-middle Miocene convergent system of the Northern Apennines (Italy): Constraints from structural and isotopic studies. Journal of Geophysical Research 115, doi: 10.1029/2009JB006590.

Vannucchi, P., Remitti, F., Phipps-Morgan, J., Bettelli, G. 2009. Aseismic-Seismic transition and fluid regime along subduction plate boundaries and a fossil example from the northern Apennines of Italy. International Geophysics 94, 37-68.

Warren, J.M., Hirth, G. 2006. Grain size sensitive deformation mechanisms in naturally deformed peridotites. Earth and Planetary Science Letters 248 (1), 438-450.

Weidinger, J.T., Schramm, J.M., Nuschej, F. 2002. Ore mineralization causing slope failure in a high-altitude mountain crest-on the collapse of an $8000 \mathrm{~m}$ peak in Nepal. Journal of Asian Earth Sciences 21 (3), 295-306.

Weidinger, J.T., Schramm, J.M., Surenian, R. 1996. On preparatory causal factors, initiating the prehistoric Tsergo Ri landslide (Langthang Himal, Nepal). Tectonophysics 260 (1), 95-107.

White, S.H., Burrows, S.E., Carreras, J., Shaw, N.D., Humphreys, F.J. 1980. On mylonites in ductile shear zones. Journal of Structural Geology 2 (1-2), 175-187.

Wintsch, R.P., Christoffersen, R., Kronenberg, A.K. 1995. Fluid-rock reaction weakening of fault zones. Journal of Geophysical Research: Solid Earth 100 (B7), 13021-13032.

Yamaguchi, A., Ishikawa, T., Kato, Y., Nozaki, T., Meneghini, F., Rowe, C.D., Kimura, G. 2014. Fluid-rock interaction recorded in black fault rocks in the Kodiak accretionary complex, Alaska. Earth, Planets and Space 66 (58), doi:10.1186/1880-5981-66-58. 